\title{
Parents Perception About Sexual Education for Adolescence With Autism
}

\author{
Atien Nur Chamidaha, Santiana Nur Jannah ${ }^{\mathrm{b}}$ \\ ${ }^{a}$ Lecturer of Special Education Department \\ ${ }^{b}$ Student of Special Education Department \\ Universitas Negeri Yogyakarta \\ Yogyakarta, Indonesia \\ Corresponding e-mail: a ${ }^{a}$ atien@uny.ac.id, ${ }^{{ }^{\text {s }} \text { santiana@gmail.com }}$
}

\begin{abstract}
This study aims to determine the perception of parents about sexual education given to adolescence with autism. This research is descriptive research with qualitative approach. The subjects of this study were three parents of autistic children who showed a sexual behavior disorder. Data collection using questionnaire and interview method. The results of this study indicate that parents consider adolescence with autism to have sexual development such as adolescents in general despite having a different speed. Parents have the view that sexual education is important for autistic children who start entering adolescence to prevent possible sexual development disorders in autistic children. However, parents do not have sufficient knowledge about it, thus having difficulties in providing reproductive health education.
\end{abstract}

Keywords: $\quad$ sexual education, autism

\section{INTRODUCTION}

Autism is a complex developmental disorder, which usually occurs at the age of one to three years. Autistic signs usually appear in the first year and before the child is three years old. Autistic children are children who have a developmental disorder that includes both verbal and nonverbal communication and social interaction, and in general the symptoms occur before the age of three [1]. Autistic children experience developmental tasks similar to other children in childhood, adolescence and adulthood. However, the adolescence of autistic children begins at different ages in each individual [2].

One aspect of development that needs to be considered in autistic children when entering adolescence is the development of sexuality. Previous research in autism special schools in Yogyakarta found some sexual behavior that is considered to be deviated by teenage autistic children [3]. These behaviors include children often touching the genitals and kissed his hands when learning in the classroom, children like to attach to the opposite sex, children like to hug people around him, children like to direct his hand to the genitals of the opposite sex, children often hold the breast and children like to rub genitals on the wall.

The emergence of problems in sexual development is encouraging the need for sexual education given to autistic children who start entering the age of adolescence. Sexual education prioritizes good behavioral education and upholds societal values [4]. Sexual education does not teach how to intercourse but the provision of reproductive health materials as a whole. Sexual education is defined as an education on the anatomy of organs that can be continued on sexual reproduction.

Sexual education is provided to prevent children from negative risks of sexual behavior. The type and depth of the material is tailored to the age, educational level and background of the child. Research obtained the result that sexual education for children with autism is something that needs to be done as early as possible [5]. Sexual education is given to autistic children not to provide as much information as possible about sexuality, but to use information more functionally.

The insensitivity of parents and teachers to the condition of adolescence causes children often get stuck in cases of sexual abuse, because children feel awkward and reluctant to ask the right people so that reinforce the reason why children often behave inappropriately to reproductive organs [6]. Limited knowledge of parents and teachers in providing services appropriate to autistic adolescence as well as children's understanding of sexual behavior can make children perform inappropriate behavior.

Today parent's role is very decisive in preparing children to face changes that will occur to them. Without prior preparation and explanation, the autistic child will feel confused and anxious about the changes that occur in the adolescent. The need for more complete parental knowledge about changes in sexual behavior of adolescent autistic 
children is to take appropriate action in handling all forms of behavioral changes shown by the child.

When parents have a positive view of providing sexual education in adolescent with autism, parents will provide understanding and explanation of sexual development. However, when parents have a negative view of providing sexual education to adolescent with autism, parents will not assume that sexual education is important given to children because it assumes that sexual is taboo. One of the factors that become obstacles for parents in addressing the problem of sexual behavior is the sense of hesitation to discuss and discuss sexual issues to children.

The importance of the role of parents in sexual education for children with autism encourages the need for a study to determine the perception of parents about sexual education for children with autism. This study was conducted to find out more details about parents' perceptions of the development and sexual education of autistic children of adolescence. This study focused on one of the special schools of autism in Yogyakarta which in previous studies have found some problems of sexual development in adolescent.

\section{RESEARCH METHOD}

This research is descriptive study with qualitative approach by describing based on questionnaire, interview and theory to explain about parent and teacher perception toward sexual education of autistic child of adolescent age. The respondentss of this study were parents of autistic children of adolescents in Citra Mulia Mandiri Autism School with criteria of having autistic children aged between 14 to 21 years old and willing to be respondents in this study. Based on these criteria we obtained three subjects with the description as follows:

Table 1. Description of Respondent

\begin{tabular}{cccc}
\hline Initial & Age & $\begin{array}{c}\text { Chikdren's } \\
\text { Age }\end{array}$ & $\begin{array}{c}\text { Children's } \\
\text { Sex }\end{array}$ \\
\hline X & 49 & 18 & Boy \\
Y & 45 & 15 & Boy \\
Z & 40 & 14 & Girl \\
\hline
\end{tabular}

Data collection techniques in this study are questionnaires and interviews. Methods of questionnaires conducted by researchers to obtain data about parents' perceptions of the development and sexual education of autistic children of adolescence. Furthermore, researchers conducted interviews to confirm the results of the questionnaire and get more details about parents' perceptions about the development and sexual education of autistic children of adolescence.

\section{RESULTS AND DISCUSSION}

\subsection{Results}

Based on the questionnaires and interviews conducted on three subjects we obtain data on knowledge and perceptions of parents about the development and sexual education of autistic children of adolescents in Citra Mulia Mandiri Autism School as follows:

Subject $X$

$\mathrm{X}$ knows that the autistic child's sexual development is similar to children in general but in autistic children the development of sexual activity can occur more slowly but also some appear faster than they should. Parents reveal that the development of autistic children is different from children in general. Nevertheless, his child has not shown a change in sexual behavior so parents say that their behavior does not indicate a disturbance or aberrations.

Subject X says that providing sexual education is essential to autistic children but he does not yet know how to provide sexual education to his child. During this time, the way that has been done by $\mathrm{X}$ to obtain information about sexual education is to follow seminars and read books about sexual learning early for autistic children.

$X$ considers the role of parents in accompanying children who are entering into adolescence in providing sexual education encompasses none of the specifics or special. Sexual education is given to flow with the development of childhood puberty. In his case, the boy is closer to her mother so the child asks her mother for help when faced with new things faced by children such as when the hair on his cock began to long the child will ask his mother's help to cut the hair.

The way that $\mathrm{X}$ providing sexual education to his child is to lead to positive things. $X$ says that one sex education materials that can be given to autistic children is the knowledge about not undressing in public places. After more detailed interviews $\mathrm{X}$ revealed that the material that can be given is to distinguish between men and women and direct the child not to perform his desire in public places. Parents can provide sexual education for children by directing children to the positive things or diverting with the busyness or activities favored by the child.

$\mathrm{X}$ argues that the role of parents and teachers is equally important in providing sexual education for children. Even the behavior of children between at home and at school is sometimes different, the child is usually more obedient to his teacher than his parents.

Subject $Y$

$Y$ states that children with special needs including autistic children experience the same 
sexual development as children in general as well as those that occur in his child. His child does not show any sexual behavior disorder. Based on the results of questionnaires and interviews, Y said that he got information about sexual education through browsing on the internet about autistic adolescents.

According to $\mathrm{Y}$ the role of parents in providing sexual education is to provide understanding about sexual as early as possible. Parents keep their children busy in doing many activities to reduce sexual behavior disorders such as taking a pool or walk every afternoon. In addition, another way in providing sexual education is to remind the child when performing a sexual behavior deviation. However, when the child does not want to be reminded, the parent can allow the child to perform the behavior as long as the behavior is less frequently. When interviewed, $\mathrm{Y}$ reveals the way in which to provide sexual education is to train the child not to engage in sexual behavior too often.

Sexual education materials that can be given to autistic children are based on the child's sexual development. However, Y has not yet known the sexual education materials that can be given to autistic children. According to $\mathrm{Y}$, things that parents need to pay attention to in order to provide sexual education to children is to explain about prohibition to perform sexual behavior in public places.

Y says that parents and teachers have a role in providing sexual education for children. Parents and teachers should have a common perception in the face of sexual problems in children. However, teachers have a greater role since parents do not know how to provide sexual education to autistic children who enter adolescence.

Subject $Z$

$Z$ revealed that autistic children experience the same sexual development with children in general, however autistic children will be slower in recognizing the opposite sex. Meanwhile, the his child has not shown any sexual behavior disorder. According to $Z$ sexual education is very important given to children who start entering adolescence. $Z$ obtain information about sexual education by reading books or electronic media and sharing with teachers and other parents.

$\mathrm{Z}$ argues that the role of parents in assisting children who enter adolescence in providing sexual education is to be a mentor and companion. When interviewed, $\mathrm{Z}$ said his role as a parent in accompanying children to provide sexual education is to be with her at all times so that parents know her sexual development. Parents provide children what they can and should not do when they are in puberty. However, $Z$ revealed not knowing the right way to provide sexual education to children. $Z$ just started to get the word "not allowed" to the child because at this time the child begins to hug someone else.

$\mathrm{Z}$ says sexual education materials that can be given to autistic children are what children can and should not do and the management of menstruation for girls. However, $\mathrm{Z}$ has not known in detail what sexual education materials can be given to autistic children of adolescence. $\mathrm{Z}$ said that the school has never provided information on sexual education materials that can be given to autistic children who have entered adolescence. $Z$ said that parents have greater role in providing sexual education because they accompanying children more longer than teachers.

\subsection{Discussion}

Based on questionnaires and interviews conducted on the three subject, result can be obtained that parents have the same knowledge about the sexual development of autistic adolescent. Parents know that children with autism have the same sexual development as teenagers in general, but some autistic children are experiencing slower sexual development and some appear prematurely. In addition, some children with autism show a disruption to their sexual development. The knowledge possessed by the parents is consistent with the results of previous studies which suggest that children with autism have the same sexual development as other children, but some children experience deviations from sexual behavior [3].

In this study parents do not find any signs of impaired sexual behavior of children with autism. Parents say that sexual behavior that is currently present in autistic children is not a disorder of sexual behavior. Sexual behavior that occurs in a teenage autistic child is normal, but the limitations of an autistic child can cause a child to engage in sexual behavior that is perceived as deviant. The autistic child's sexual development in terms of social and cognitive skills are limited to make it difficult for children to understand their sexual interests and desires [2].

Parents assume that the importance of sexual education is given to autistic children who start entering adolescence. Sexual education is given to autistic children who begin to enter adolescence to understand the puberty and prohibited to perform sexual behavior in public places. However, parents still experience many obstacles in providing sexual education for autistic children both from the inhibitions of the parents and the condition of the child. Sexual education is given incidentally when the child does a sexual behavior then that's when parents will provide a learning / understanding to the child. The results of this study reinforce the previous study [7] which says that parents' knowledge of the sexual education of autistic 
adolescence is low. It can be influenced by the acquisition of information owned by parentsand the attitude of parents who are taboo to provide sexual education.

Parents need the cooperation of teachers in providing sexual education because there are differences in sexual behavior that children do at home and at school. In obtaining information about sexual education for autistic children, parents seek information through reading early sexual learning books for autistic children, through internet or electronic media about autistic children of adolescence, attending reproduction seminars for autistic adolescents, communication with classroom teachers teaching Children, and sharring with other parents who are more experienced in assisting children when they are in their teens.

In addition, parents do not know the material that will be given to children because schools have not provided information to parents about systematic sexual education. Matter that is known by parents are differentiation between men and women, what children can and should not do, open clothes in public place, directing children to perform their desire in closed place and additional material of sexual education for girl about handling the menstruation. Sexual education materials that parents can provide to adolescent autistic children are education covering the nakedness, education of preservation, knowledge of sexual organs, religious education, simple behavior, reproductive health education, violence and sexual harassment, adolescent sexual behavior and its effects, the process of fertilization in the creation of man, the protection of the law against acts of sexual violence [8]. Sexual education materials that parents give to children should be systematic and tailored to the child's condition. In addition, the depth of material given by each child will vary according to the child's ability and understanding.

Parents in providing sexual education follow the child's sexual development. When children engage in sexual behavior, parents will provide sexual education directly. When children masturbate parents will warn but when children can not be warned it will be left by parents as long as the child is not too frequent and do not perform sexual behavior in public place. When the child is forced to not perform sexual behavior will result in tantrums and children become more hyperactive.

What parents need to consider in providing sexual education for autistic children in adolescence is guiding and directing when children's puberty has appeared to the positive, or diverted with the activity that children loves. Sexual behavior is not in public and not excessive, need patience and consistency, child sex hormones, and the habits of children when wanting to menstruate. Moreover,concerning things that need to be considered by parents in providing sexual education is the way of delivering it should be reasonable and simple, the content of the description submitted must be objective in accordance with the child's condition, shallow or in depth the content of the description should be tailored to the needs and with the stage of sexual development of children. Sexual education should be given personally, because the extent of the narrowness of knowledge with the slow pace of development is not the same every child and the autistic child's sexual education needs to be given gradually and repeatedly so that children can really understand the sexual education materia . Parents can do things that have been described above in order to facilitate in providing sexual education to autistic children of adolescence.

\section{CONCLUSIONS}

Parents have appropriate knowledge about the sexual development of autistic adolescents. Parents have a perception that sexual education is important given to autistic children who start entering adolescence, however parents do not have enough knowledge about the materials and methods of appropriate sexual education for children with autism. In addition, conditions and abilities possessed by autistic children make parents provide sexual education incidentally in accordance with the child's sexual development. Therefore, parents need to get training and mentoring about sexual education in autistic children who start entering adolescence.

\section{REFERENCES}

[1] Hallahan Daniel P., Kauffman James M. \& Pullen Paige C. (2009). Exceptional Learners an Introduction to Special Education. United States of America: Pearson Education, Inc.

[2] Widyasti, F. T. (2009). Sexuality of Adolescent with Autism in Puberty. Thesis retrieved from http://eprints.undip.ac.id/10958/1/jurnal.pdf

[3] Chamidah, A. N. \& Sukinah. (2015). The needs of information technology based media to teach sexual education for children with autism. Proceeding 2nd International Conference on Current Issuess in Education. Yogyakarta: Universitas Negeri Yogyakarta.

[4] Wuryani, S. E. D. (2008). Family Sex Education. Jakarta: Grasindo,.

[5] Masyitah, Z. L. Strategy and method of sexual education for children with autism. Thesis. (2015). Retrieved from http://digilib.uinsuka.ac.id/16167/1/BAB I, V, DAFTAR PUSTAKA.pdf

[6] Muzayyanah. Impact of free sexual behaviour for adolescent health. 2008. Retrieved from 
$\underline{\text { www.halalsehat.com/Remaja- }}$

Sukses/DAMPAK-PERILAKU-SEKS-

BEBAS-BAGI-KESEHATAN-REMAJA-

.html

[7] Sholihatina, A. (2012). Knowledge and attitudes of parents about sexual education for autistic adolescent on puberty phase at SLBN Cibiru and SLB Pelita Hafidz Bandung. Thesis. Retrieved from http://jurnal.unpad.ac.id/ejournal/article/view/7 $33 / 779$

[8] Azis, S. (2015). Sexual education for children with autism. Yogyakarta: Gaya Media. 